\title{
Inproved Math Connection Skills Through Online Learning Using MATH-UNWIR
}

\author{
Diki Mulyana', Mochammad Taufan², Luthfiyati Nurafifah ${ }^{3}$ \\ 1,2,3 Mathematics Education, University Wiralodra, Indramayu, Indonesia \\ 1ㅁiki.mulyana@unwir.ac.id, ${ }^{2}$ mochammad.taufan@unwir.ac.id, 3 luthfiyati.nurafifah@unwir.ac.id
}

\begin{tabular}{|c|c|}
\hline & ABSTRACT \\
\hline Article History: & \multirow{9}{*}{$\begin{array}{l}\text { Advances in technology and learning carried out online due to the Covid-19 } \\
\text { pandemic are the background for this research. Research objectives to determine } \\
\text { the effectiveness of online learning using MATH-UNWIR in improving } \\
\text { mathematical connection ability and online learning amid the pandemic Covid-19. } \\
\text { This study uses quantitative research with a quasi-type experimental design, as } \\
\text { well as a research design using pretest and posttest experimental classes. There } \\
\text { are } 15 \text { students as research sample. The instruments used was connection skill } \\
\text { test and questionare. The data obtained anylized with quantitative method. The } \\
\text { average yield pretest was } 56,33 \text { and the posttest mean was } 81,67 \text {. The results of } \\
\text { the pretest posttest paired sample t-test showed that there was an average } \\
\text { difference significant between pretest and posttest results, so that it brought to an } \\
\text { effect of online learning using MATH-UNWIR on students' mathematical } \\
\text { connections. The result of the N-Gain score was 0.57. That means it is in the } \\
\text { medium category and shows a percentage of 57\%. In this study it can be } \\
\text { concluded that there is significant influence online learning' using MATH-UNWIR } \\
\text { to improve students' mathematical connections with the interpretation of the } \\
\text { effectiveness of increasing mathematical connections quite effectively. }\end{array}$} \\
\hline Received : 07-01-2021 & \\
\hline Revised : :01-0 & \\
\hline $\begin{array}{ll}\text { Accepted } & : 03-04-2021 \\
\text { Online } & : 16-04-2021\end{array}$ & \\
\hline Keywords: & \\
\hline $\begin{array}{l}\text { Online Learning; } \\
\text { MATH-UNWIR; }\end{array}$ & \\
\hline Mathematical & \\
\hline Connection. & \\
\hline & \\
\hline
\end{tabular}

\begin{tabular}{cc}
\hline doi $Y$ Crossref & (c) (i) (0) \\
https://doi.org/10.31764/itam.v5i1.3828 & This is an open access article under the CC-BY-SA license \\
\hline
\end{tabular}

\section{A. INTRODUCTION}

Online education technology has developed rapidly in the education system. Technological advances that have occurred have created a significant impact on various aspects of human life, including business, government, and people's lifestyles. As a result, Education 4.0 was founded in response to the impact it has had on education systems around the world. Apart from the educational revolution, the Covid-19 pandemic is another force driving the adoption of online teaching and learning among lecturers. In December 2019, the Covid-19 outbreak starting to hit the global economy and people's lifestyles (Atkeson, 2020). According to Keaton \& Gilbert (2020), the current Covid-19 epidemic has highlighted the virtual world of education in a way that has never been done before a different online learning method to fill the void in the current education rules. In accordance with (Giatman et al., 2020), many educational institutions try to answer the government's invitation by using online learning, but teachers and students are not ready because technology infrastructure is not good (Anita Azmi et al., 2020), on the other hand Telaumbanua (2020) argues that starting working from home (WFH) and taking action possible remotely via an online system. The central 
government policy must immediately be followed up by Wiralodara Indramayu University (UNWIR) which confirms the transfer of all face-to-face lecture activities to online lectures. With these conditions, Wiralodra University changing learning that using conventional methods to online methods is certainly not an easy and simple thing (Atsani, 2020).

Several records state that education proficiency in Indonesia is still low in comparison to educational proficiency in other countries. Another note also states that in various discussions on education in Indonesia, particularly mathematics education, what is interesting is quality mathematics education, which is thought to considered alarm. This situation is of course very ironic when it comes to the role of mathematics as a basis for developing science and technology. Facilitates college student independent learning, the use of learning media is an alternative in cultivation of developing learning for the better. Zain et al., (2019) it is said that an important aspects of technology is the extent to which students accept and use technology. The internet, which has entered the field of education within this decade, allows internetbased learning to occur with computers as the medium. By way of cultivate online learning, students can be independently understand material that appears abstract and nothing is easy to visualize. In addition, it is hoped that students as prospective mathematics, teachers will be motivated and able to actively participate in the classroom learning. According to (Zhu, 2012), there is a positive relationship between achievement and satisfaction. Meanwhile, Abuhassna \& Yahaya (2018) argues that website-based distance learning makes a significant contribution in improving distance learning and students. Learning mathematics using online learning is a form of curriculum realization in the department of mathematics education, and it was hoped that student can play an active role and learn independently in the capita selecta intermediate level' mathematics course so that it can improve students' mathematical connection skills. Various models of learning can be developed by utilizing the information technologies to be more creations, according to (Wen \& Hua, 2020), the types of online education technology used in several curriculum models, in terms of three main factors that teachers can use on online educational technology during the Covid-19 pandemic: (1) technology education online; (2) teaching competence; and (3) online infrastructure and resources. Allen et al., (2016) define online learning as learning the most of the content is online delivered. However, learning that can be applied to online educational technology, including blended and web facilitated courses. Blended learning is combined face-to-face and online teaching (Graham, 2013). An example of blended learning is the classroom approach, where the presentation of material has shifted to home activities, and activities traditionally seen as homework have turned into classroom activities. Online education technology integration occurs when teachers deliver learning content through online applications, and students are responsible for managing their learning (Hui-Chen Lin \& Gwo-Jen Hwang, 2019). Use web-based technology to facilitate face-to-face interactions (Allen et al., 2016). In this learning, teachers can use a Learning Management System (LMS) as a platform to provide students with materials and assignments. Web facilitated courses using the minimum amount of online educational technology in teaching. Although a different proportion of content is delivered online, teachers or instructors in this type of teaching adopt some online technology education in delivering learning content. As online education is gaining more and more attention, many online education technologies have been developed in recent years. Online 
education technology is any program, application, or technology that can be accessed via an internet connection (Saadé \& Al Sharhan, 2015). These tools are used to enhance competencies in presenting information and students' ability in accessing information. One example of online education technology is Google Classroom, a virtual class that contributes teachers save time, maintain class and fix interpersonal communication skills among student (Iftakhar, 2016). In addition, there are online game-based learning tools, such as Cahoots, Quizizz, Quizlet and Plickers quizzes that help teachers assess student learning progress in a fun environment. This online game-based learning tool increases the effectiveness of cultivate learning (Qin \& Hua, 2020; Yanawut Chaiyo, 2017; Zarzycka-Piskorz, 2016). Several social media applications, such as Twitter, Facebook, WhatsApp, Snapchat, and Instagram were adopted for the delivery of material and as a practical means for students to present the skills learned (Hamat \& Hassan, 2019). There are many online educational technologies that teachers can adopt an inrease effectiveness of cultivate learning.

According to the opinion above, online learning can be interpreted as learning that harness media in the form of applications, software, website, and etcetera. Switch online learning, cultivate learning does not only listen to material descriptions from lecturers but students also carry out another action like observing, doing, showing, and so on. The material is depicted in various forms and is more dynamic plus interactive so student are motivated to be involved learning. One reason online medium that can be used is a learning website. Aqip (2013) explain that there are three possibilities in developing internet based learning, namely web courses, web centric courses, and web internet based learning enhanced courses. A web centric course of the web for educational purposes that make distance learning face to face. Web centered courses have these gains as web centric courses, some teaching materials, research, conferencing, assignments and practice questions sent over the internet, during the exam questions, lots of delivery and training materials are carried out face to face. Media that was originally used slates and limestone shifted to the use of computers and the internet to the learning method is done face to face gradually switching to virtual learning. College environment, take advantage of cultivate learning carried out by wearing a website can overcome some of the obstacles to ordinary learning, especially the limitations education material, study reference and time can be simplified with help website lectures. This helps cultivate learning, for lecturers to illustrate concept maps, recovery objectives, and various perceptual problems on website, so student can study them before lectures take place. The goal is that student has provided themselves before lectures take place so that lectures can be maximized. This is supported by relevant online learning research such as (Means et al., 2016; Peters-Burton et al., 2014); teachers' perspectives on research (Borup, 2016b; Micah N. Bruce-Davis, E. Jean Gubbins, Cindy M. Gilson, Merzili Villanueva, Jennifer L. Foreman, 2014) and parental involvement is found in research(Borup, 2016a; Lisa Hasler Waters, 2014); Meanwhile, research is seen through the perspective of students such as (Borup et al., 2019; Hawkins et al., 2013; Kim et al., 2015; Oviatt et al., 2016; Turley \& Graham, 2019); only a few studies on the scope of students including (Hasler-waters et al., 2014).

Among the media that can be used on mathematics cultivate learning is the MATH-UNWIR this website is a secure learning platform for faculty, students and campus based. MATHUNWIR presents the right and appropriate way to classes to acquire and cooperate, share 
topics as well access jobs, quality, plus announcement. Advantage MATH-UNWIR is to guide lecturers virtual array classes prepare evidence class section on lectures, there are assignments, practice questions, and evaluation at the end of the lecture. Then the website will make learning easier and find out growth in student connections. Students and lecturers have not taken full advantage of technological developments, especially social media. It is also thought to have affect student attention. Interestingly, this can be interpreted as a desire that arises from within the students themselves.

Capita Selecta intermediate level mathematics is an important subject taught in the Mathematics Study Program. Bey \& Asriani (2013), the assumption that mathematics becomes one of the basic sciences that captures an important task in the growth of science and technology. Mathematical connection ability is the hope that every institution of education wants to achieve. Students' mathematical connection ability is an ability that would be explored in this research. This ability includes higher-order thinking skills and would be explored through the use of online learning media. The advantages of online media in clarifying mathematical ideas can require students to investigate and analyze, carry out and investigate ideas as well as the basis provided in the material they face, so that it comparative builds a structure for student understanding.

According to the description, researcher will be know the increase of students' mathematical connection ability in mathematics learning use the application of the e-learning design for the website based in capita selecta' intermediate level mathematics with MATHUNWIR. The purpose of this study was to determine the effectiveness of online learning using MATH-UNWIR in improving mathematical connection skills and learn online during Covid-19.

\section{B. METHODS}

Research method used is quantitative research method. This study were carried out at the University of Wiralodra Indramayu, the fifth semester of the department of mathematics education in capita selecta intermediate level mathematics. This study used a quasiexperimental design type with pretest and posttest research group experiment. The type of connection skill test is Essay test (10 questions) for pretest and posttest. Data collection and instrument analysis tests get through questionnaires aim to determine student attention mathematics learn to use website based MATH-UNWIR, descriptive tests aim to determine the improvement of students' mathematical connection ability after study, Documentation aims to obtain written data about the condition of the research subject. The prerequisite test analysis tool uses the product moment formula to check nolmality of data. The data analysis consisted of the analysis of the test values using t-test and N-Gain, In this study using SPSS.

The effectiveness of online learning using MATH-UNWIR was measured from the results of the gain value which was used to see the effectiveness of the application of online learned used MATH-UNWIR based on the results of the pretest and posttest scores. Effectiveness is determined in accordance with the calculation of the N-Gain score from average pretest and posttest scores of 15 students. The calculation of the N-Gain score is carried out according to the formula:

$$
\text { Gain Score }=\frac{(\% \text { posttest mean score }-\% \text { pretest mean score }}{(100 \%-\% \text { pretest mean score })}
$$


The N-Gain criteria can be seen in table 1, while the effectiveness category in accordance with the N-Gain score can be seen in table 2.

Table 1. N-Gain Score criteria

\begin{tabular}{cc}
\hline Gain Score result & Criteria \\
\hline Gain $>0.7$ & High \\
$0.7 \geq$ Gain $\geq 0.3$ & medium \\
Gain $<0.3$ & lower \\
\hline
\end{tabular}

Source: Hake (1998) in Nashiroh et al., (2020).

Table 2. Prediction criteria of the Gain Ectivity

\begin{tabular}{cl}
\hline Percentage (\%) & \multicolumn{1}{c}{ Prediction } \\
\hline$<40$ & Ineffective \\
$40-55$ & Less effective \\
$56-75$ & Quit effective \\
$<76$ & Effective \\
Source: Arikunto (1999) in Nashiron et al., (2020).
\end{tabular}

\section{RESULT AND DISCUSSION}

\section{Learning Activity By Using MATH-UNWIR}

The application of website-based online learning design with MATH-UNWIR can guide students in mathematics lectures. MATH-UNWIR is website based that provide safety and easy way to classes to relate and work together, various topics, and achieve work, lecture assessments, announcements, and can guide lecturers virtual structure classes based on reality classes In the lecture, there are materials, assignments, exercises and assessments at the end of the lecture.
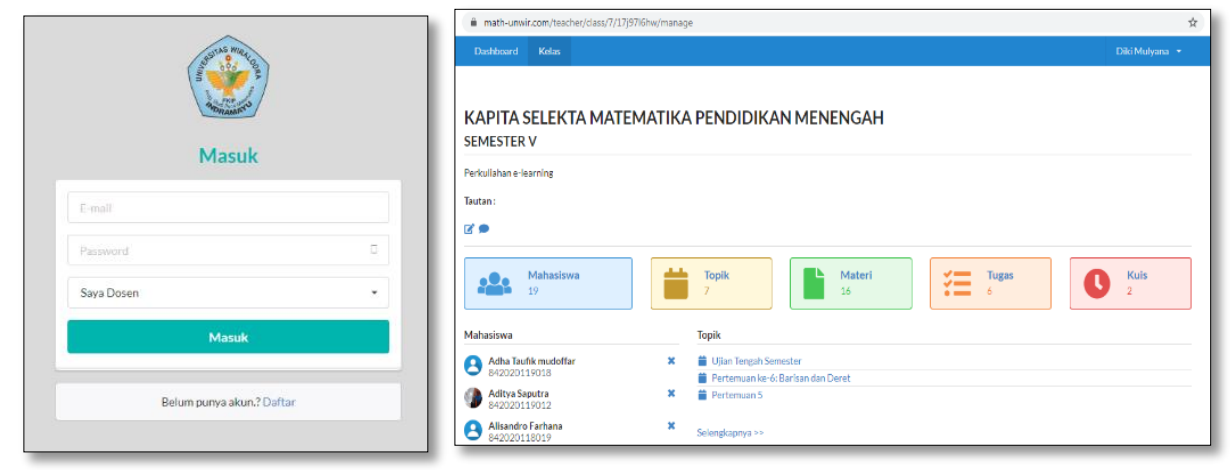

Figure 1. MATH-UNWIR website

MATH-UNWIR is used in learning with normal online and face-to-face meetings. Using MATH-UNWIR, online learning is combined with learning that takes place outside of class time. such content according to research conducted by Giatman et al., (2020) regarding online learning quality control during Covid-19 in Indonesia and Yustinaningrum (2018) is a model of e-learning web-based use application edmodo can improve students' attention on learning mathematics. Material with assignments are entered into MATH-UNWIR so that students 
become lightly reached them outside of class time. Use online design with MATH-UNWIR application so that students get used to it independent learn in access the assigned task. But, lecturer still carry out teaching and cultivate learning in the grade. Use of the online learning design using MATH-UNWIR can train students to be independent in learning as well as make students excited in finding material sources before studying in class, have online discussions about being given assignments along with completing assignments on time. In line with (Anderson \& Mccormick, 2005) that online learning needs to pay attention to: (a) in accordance with the curriculum, $(b)$ is inclusive, $(c)$ involves students, $(d)$ is innovative, $(e)$ effective learning, $(f)$ evaluation, $(g)$ consistent, $(h)$ easy to operate, $(i)$ cost-effective. Furthermore, (Asarta \& Schmidt, 2020) emphasizes (a) the contact of students and educators, $(b)$ collaboration between students, $(c)$ an active learning atmosphere, $(d)$ fast feedback, $(e)$ achievement of learning objectives, and $(f)$ respect differences. Online learning design using MATH-UNWIR in Figure 2.

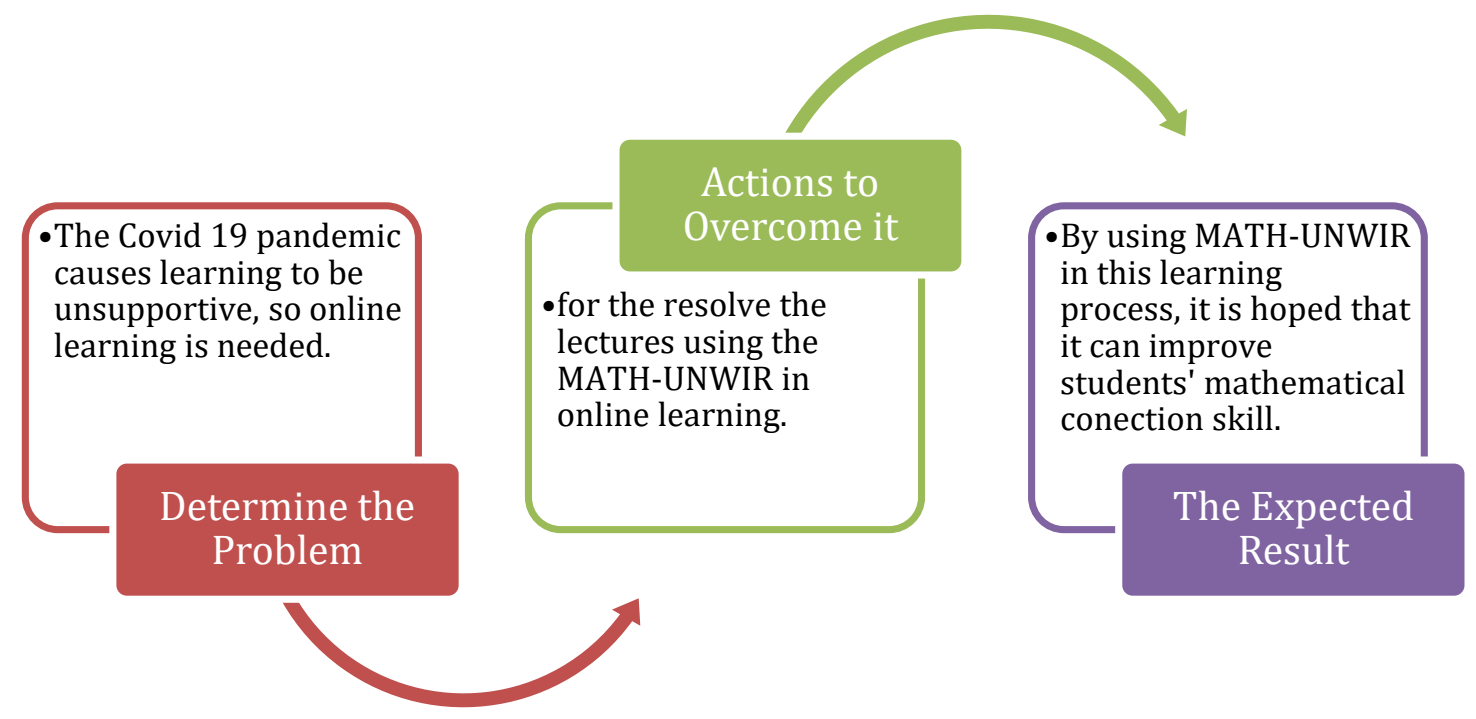

Figure 2. Online learning using MATH-UNWIR.com

Learning begins face-to-face using zoom metting and continues with the delivery of material from the lecturer. After that, opening the MATH-UNWIR website using their respective accounts. There is learning material in the form of modules (files), learning videos (files and youtube). After getting the material, it is continued with the completion of Student Worksheets (LKM) as a lecture assignment, to improve students' mathematical connections.

With the Covid-19 pandemic, all learning activities carried out in face-to-face class must be carried out in their respective homes because they do not support the conditions for learning carried out on campus, therefore lecturers use an online learning system. In this case it results in obstruction of cultivate learning, namely the mismatch of expectations from cultivate learning because when you see the conditions that occur in the field that learning using an online system is not as effective as when implementing learning in class. Therefore, lecturers must use learning that is able to produce cultivate learning that is in accordance with the expected goals. Thus the author uses MATH-UNWIR in an online learning system. Using MATH-UNWIR is expected to help cultivate learning and be able to create learning in accordance with the expected goals. In this study, an analysis of the use of MATH-UNWIR in 
the capita selecta intermediate level' mathematics course was conducted to see whether the use of MATH-UNWIR can facilitate learning activities and whether its use is optimal, whether lecturers and students understand learning using MATH-UNWIR. As the efforts of lecturers in overcoming deficiencies in carrying out learning by using MATH-UNWIR.

\section{The Effect Of Learning Implementation Using MATH-UNWIR}

This experimental research began with pretest activity and ended with a posttest activity, using 10 descriptive questions. The test results were then processed using descriptive and inferential statistics to identify the effect of independent variables on the dependent variable. The data in Table 3 is the result of descriptive statistical calculations from the pretest and posttest results.

Table 3. Descriptive Statistical Data of Pretest and Posttest Results

\begin{tabular}{lllrrr}
\hline & \multicolumn{5}{c}{ Group Statistics } \\
\hline Mathematical & Group & N & Mean & Std. Deviation & Std. Error Mean \\
\cline { 2 - 6 } Connection & Pretest & 15 & 81.67 & 5.876 & 1.517 \\
\hline
\end{tabular}

Accordance with the data results processing, it was found that there were 15 students in the experimental class in this study. Posttest experimental class had an average value of 81.67 with a standard deviation of 5.40, while the pre-test experimental class had an average value of 56.33, with a standard deviation of 9.72. So that in table 1 it can be seen that the pretest mean is lower than the posttest mean. This shows that descriptively there is a difference in the average value of mathematical connection ability in the pretest and posttest after doing online learning using MATH-UNWIR. This can already indicate a significant influence between two variables, but it is necessary to test the hypothesis using the paired sample t-test on the results of the pretest and posttest.

Hypothesis testing can be done if the classical assumption tests have been fulfilled, that is, the research data must be normally distributed. Normally distributed, data can be known from the normality test. In this calculation, the researcher used the Kolmogorov-Smirnov Normality Test. The results of the normality test may be noted in Table 4.

Table 4. Tests of Normality

\begin{tabular}{|c|c|c|c|}
\hline & \multicolumn{3}{|c|}{ Kolmogorov-Smirnova } \\
\hline & Statistic & Df & Sig. \\
\hline Pretest & ,214 & 15 &, 064 \\
\hline Posttest & 205 & 15 &, 090 \\
\hline
\end{tabular}

a. Lilliefors Significance Correction

The normality test was carried out by SPSS using the Kolmogorov-Smirnov. With a significance evel of 5\%. In accordance with the normality test, sig value is obtained. Mathematical connection ability (Pre-Test) $=0.064>0.05$, so that the distribution of mathematical connection ability data (Pre-Test) is normally distributed. Mathematical connection ability (Post-Test) $=0.090>0.05$, so that the data distribution of mathematical connection ability (Post-Test) is normally distributed. So that the statistical test can be continued by conducting 
hypothesis testing using paired sample t-test. The results of the paired sample t-test between the pretest and posttest values can be seen in Table 5 .

Tabel 5. Paired Samples t-test

\begin{tabular}{|c|c|c|c|c|c|c|c|c|c|}
\hline & & \multicolumn{5}{|c|}{ Paired Differences } & \multirow[t]{3}{*}{$\mathbf{T}$} & \multirow[t]{3}{*}{ df } & \multirow{3}{*}{$\begin{array}{l}\text { Sig. (2- } \\
\text { tailed) }\end{array}$} \\
\hline & & \multirow[t]{2}{*}{ Mean } & \multirow[t]{2}{*}{$\begin{array}{l}\text { Std. } \\
\text { Deviati } \\
\text { on }\end{array}$} & \multirow[t]{2}{*}{$\begin{array}{l}\text { Std. } \\
\text { Error } \\
\text { Mean }\end{array}$} & \multicolumn{2}{|c|}{$\begin{array}{l}95 \% \text { Confidence } \\
\text { Interval of the } \\
\text { Difference }\end{array}$} & & & \\
\hline & & & & & Lower & Upper & & & \\
\hline $\begin{array}{l}\text { Mathematical } \\
\text { Connection }\end{array}$ & $\begin{array}{l}\text { Pretest - } \\
\text { Posttest }\end{array}$ & $-25,333$ & 8,549 & 2,207 & $-30,067$ & $-20,598$ & $-11,476$ & 15 & ,000 \\
\hline
\end{tabular}

According to Table 5, it is known that Sig. (2-tailed) was $0.000<0.05$, that it was obtained that $\mathrm{H}_{0}$ was rejected and $\mathrm{H}_{\mathrm{a}}$ was accepted, reached the conclusion of the hypothesis so that there was an average difference between the pretest and posttest results, which means that online learning using MATH-UNWIR has an effect on increasing the ability of mathematical connections. In the capita Selecta intermediate level mathematics.

\section{Effectiveness of Online Learning Using MATH-UNWIR}

The data in table 6 shows the $\mathrm{N}$-gain value of 0.57 . in accordance with table 4 of $\mathrm{N}$-Gain Score criteria, obtained the $\mathrm{N}$-Gain value is included in the moderate criteria. Meanwhile, if it is seen from table 5 , the category of gain effectiveness interpretation is based on percentage, then the $\mathrm{N}$-Gain gain of $57 \%$ is included in the moderate effective interpretation category. The results showed that there was an uplift in pretest and posttest mean scores. Count result $\mathrm{N}$ Gain can be seen at Table 6 as follows:

Table. 6 Count results N-Gain Score

\begin{tabular}{cccccc}
\hline $\begin{array}{c}\text { Average } \\
\text { Pretest }\end{array}$ & $\begin{array}{c}\text { Average } \\
\text { Posttest }\end{array}$ & Gain Score & Percentage & $\begin{array}{c}\text { N-gain } \\
\text { Minimum }\end{array}$ & $\begin{array}{c}\text { N-gain } \\
\text { Maximum }\end{array}$ \\
\hline 56.33 & 81.67 & 0.57 & $57 \%$ & 28.57 & 75.00 \\
\hline
\end{tabular}

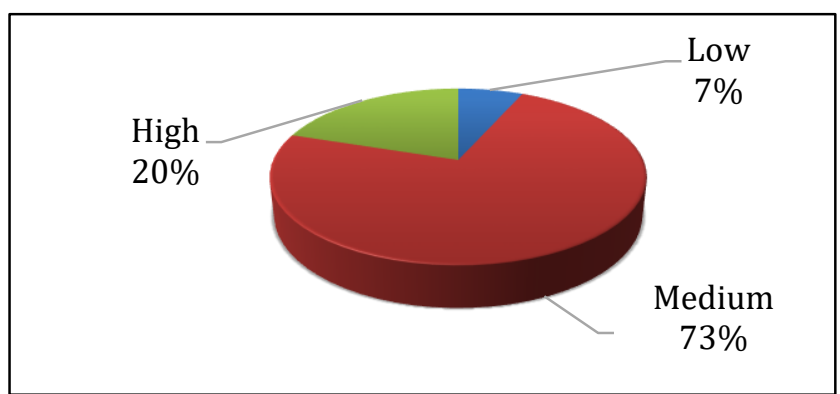

Figure 3. Percentage of student N-Gain score

Student N-Gain Score result based on low, medium, and high categories in Figure 3. The total of student who obtained low $\mathrm{N}$-Gain scores was 1 person with a proportion of $7 \%$ of total students. The total of students who obtained moderate $\mathrm{N}$-Gain scores was 11 people with a percentage of $73 \%$ of the total students. While the total of students who obtained high N-Gain scores was 3 people with a percentage of $20 \%$ of the total students. Based on the data on the distribution of students' $\mathrm{N}$-Gain scores, the average $\mathrm{N}$-Gain and the percentage, it can be concluded that online learning using MATH-UNWIR is quite effective in improving students' mathematical connection skills in capita selecta' intermediate level mathematics 


\section{CONCLUSION AND SUGGESTIONS}

In accordance with the results of research and discussion was obtained as follows: (1) there are differences in the mean pretest and posttest scores by looking at the test results, obtained the value of Sig. $000=0 \%$, the average value sig $<5 \%$, so it can be ascertained that $\mathrm{H}_{0}$ was not accepted and $\mathrm{H}_{\mathrm{a}}$ was accepted, so it concluded that there was an average difference between the pretest and posttest results, which means that there was an effect of online learning using MATH-UNWIR to improve students' mathematical connections in capita selecta intermediate level mathematics. (2) the increase in online learning using MATH-UNWIR was indicated by the mean value of the $\mathrm{N}$-gain score for the experimental class using MATHUNWIR was 0.57, the N-Gain value obtained was included in the medium criteria and percentage category of $\mathrm{N}$-Gain effectiveness interpretation, the gain of $\mathrm{N}$-Gain $57 \%$ is included in the category of Effective Enough.

Based on the above conclusions, the researcher provides the following suggestions: (a) for educators, it was found that lecturers can used MATH-UNWIR online learning media to improve students' mathematical connections. Lecturers can get past various distractions in online learning due to conditions of the Covid-19 period and in particular limited teaching materials, references and time. (b) For other researchers, complete the research by adding a control class as a comparison of this learning model.

\section{ACKNOWLEDGEMENT}

The author thanks Directorate of Research and Community Service Directorate General of Research and Development Strengthening Ministry of Research, Technology and Higher Education of the Republic of Indonesia, who has funded this research, rector of Wiralodra University Dr. Ujang Suratno,SH.,M.Si, LPPM Wiralodra University Ir. Yudhi Mahmud, M.P and to the Dean of the FKIP, Wiralodra University, Dr. Runisah, M.Pd for giving permission to use student test scores. This work is made possible through the generous cooperation and assistance of all the lecturers in our department as well as the participating students.

\section{REFERENCES}

Abuhassna, H., \& Yahaya, N. (2018). Students' utilization of distance learning through an interventional online module based on moore transactional distance theory. Eurasia Journal of Mathematics, Science and Technology Education, 14(7), 3043-3052. https://doi.org/10.29333/ejmste/91606

Allen, I. E., Seaman, J., Poulin, R., \& Straut, T. T. (2016). Online report card: Tracking online education in the UnitedStates. Babson Survey Research Group and Quahog Research Group, LLC.

Anderson, J., \& Mccormick, P. R. (2005). Ten Pedagogic Principles for E-learning. Insight, December, 68.

Anita Azmi, R., Rukun, K., \& Maksum, H. (2020). Analisis Kebutuhan Pengembangan Media Pembelajaran Berbasis Web Mata Pelajaran Administrasi Infrastruktur Jaringan. Jurnal Imiah Pendidikan Dan Pembelajaran, 4 (2), https://ejournal.undiksha.ac.id/index.php/JIPP/article/view/25840/15852

Aqip, Z. (2013). Model-Model, Media, dan strategi pembelajaran kontekstual inovatif. Yrama Widya.

Asarta, C. J., \& Schmidt, J. R. (2020). The effects of online and blended experience on outcomes in a blended learning environment. Internet and Higher Education. https://doi.org/10.1016/j.iheduc.2019.100708

Atkeson, A. (2020). What Will Be the Economic Impact of COVID-19 in the US? Rough Estimates of Disease Scenarios. In NBER Working Paper 26867.

Atsani, K. L. G. M. Z. (2020). Transformasi Media Pembelajaran Pada Masa Pandemi Covid-19. Jurnal Teknologi Pendidikan, 22(1), 65-70. http://journal.unj.ac.id/unj/index.php/jtp 
Bey, A., \& Asriani, A. (2013). Penerapan Pembelajaran Problem Solving untuk Meningkatkan Aktivitas dan Hasil Belajar Matematika pada Materi SPLDV Jurusan PMIPA-FKIP Universitas Halu Oleo. Jurnal Pendidikan Matematika, 4(2), 223-239.

Borup, J. (2016a). Teacher perceptions of learner-learner engagement at a cyber high school. International Review of Research in Open and Distance Learning, 17(3), 231-250. https://doi.org/10.19173/irrodl.v17i3.2361

Borup, J. (2016b). Teacher Perceptions of Parent Engagement at a Cyber High School. Journal of Research on Technology in Education, 48(2), 67-83. https://doi.org/10.1080/15391523.2016.1146560

Borup, J., Chambers, C. B., \& Stimson, R. (2019). K-12 student perceptions of online teacher and on-site facilitator support in supplemental online courses. Online Learning Journal, 23(4), 253-280. https://doi.org/10.24059/olj.v23i4.1565

Giatman, M., Siswati, S., \& Basri, I. Y. (2020). Online Learning Quality Control in the Pandemic Covid-19 Era in Indonesia. Journal of Nonformal Education, 6(2), 168-175. https://journal.unnes.ac.id/nju/index.php/jne

Graham, C. R. (2013). Emerging practice and research in blended learning Running Head: RESEARCH IN BLENDED LEARNING The following is a draft version from a chapter soon to be printed in the Handbook of Distance Education . Graham , C . R . (2013). Emerging practice and rese. January 2013.

Hamat, A., \& Hassan, H. A. (2019). Use of social media for informal language learning by Malaysian University Students. 3L: Language, Linguistics, Literature, 25(4), 68-83. https://doi.org/10.17576/3L-2019-2504-05

Hasler-waters, L., Barbour, M. K., \& Menchaca, M. P. (2014). The Nature of Online Charter Schools: Evolution and Emerging Concerns. 17, 379-389.

Hawkins, A., Graham, C. R., Sudweeks, R. R., \& Barbour, M. K. (2013). Academic performance, course completion rates, and student perception of the quality and frequency of interaction in a virtual high school. Distance Education, 34(1), 64-83. https://doi.org/10.1080/01587919.2013.770430

Hui-Chen Lin \& Gwo-Jen Hwang. (2019). Research trends of flipped classroom studies for medical courses: a review of journal publications from 2008 to 2017 based on the technology-enhanced learning model. Interactive Learning Environments, 27(8), 1011-1027. https://doi.org/10.1080/10494820.2018.1467462

Iftakhar, S. (2016). Google classroom: what works and how? 3, 12-18.

Keaton, W., \& Gilbert, A. (2020). Successful Online Learning: What Does Learner Interaction with Peers, Instructors and Parents Look Like? Journal of Online Learning Research.

Kim, C., Park, S. W., Cozart, J., \& Lee, H. (2015). From motivation to engagement: The role of effort regulation of virtual high school students in mathematics courses. Journal of Educational Technology \& Society, 18(4), 261-272.

Lisa Hasler Waters, P. L. (2014). Who is Teaching? New Roles for Teachers and Parents in Cyber Charter Schools. Journal of Technology and Teacher Education, 22(1), 33-56. https://www.learntechlib.org/primary/p/112373/

Means, B., Wang, H., Young, V., Peters, V. L., \& Lynch, S. J. (2016). STEM-focused high schools as a strategy for enhancing readiness for postsecondary STEM programs. Journal of Research in Science Teaching, 53(5), 709-736. https://doi.org/10.1002/tea.21313

Micah N. Bruce-Davis, E. Jean Gubbins, Cindy M. Gilson, Merzili Villanueva, Jennifer L. Foreman, L. D. R. (2014). STEM High School Administrators', Teachers', and Students' Perceptions of Curricular and Instructional Strategies and Practices. Journal of Advanced Academics, 25(3), 272-306. https://doi.org/10.1177/1932202X14527952

Nashiroh, P. K., Ekarini, F., \& Ristanto, R. D. (2020). Efektivitas Penerapan Model Pembelajaran Kooperatif Tipe Jigsaw Berbatuan Mind Map terhadap Kemampuan Pedagogik Mahasiswa Mata Kuliah Pengembangan Program Diklat. Jurnal Pendidikan Teknologi Dan Kejuruan, 17(1), 43. https://doi.org/10.23887/jptk-undiksha.v17i1.22906

Oviatt, D. R., Graham, C. R., Davies, R. S., \& Borup, J. (2016). Online student use of a proximate community of engagement in an independent study program. Online Learning Journal, 22(1), 223-251. https://doi.org/10.24059/olj.v22i1.1153 
Peters-Burton, E. E., Lynch, S. J., Behrend, T. S., \& Means, B. B. (2014). Inclusive STEM High School Design: 10 Critical Components. Theory into Practice, 53(1), 64-71. https://doi.org/10.1080/00405841.2014.862125

Qin, T. P., \& Hua, T. K. (2020). In-game instructions: The extent of their usefulness in enhancing the vocabulary acquisition of ESL learners. International Journal of Emerging Technologies in Learning, 15(4), 73-89. https://doi.org/10.3991/ijet.v15i04.11647

Saadé, R. G., \& Al Sharhan, J. (2015). Discovering the motivations of students when using an online learning tool. Journal of Information Technology Education: Research, 14(2015), 283-296. https://doi.org/10.28945/2271

Telaumbanua, D. (2020). Urgensi Pembentukan Aturan Terkait Pencegahan Covid-19 di Indonesia. QALAMUNA: Jurnal Pendidikan, Sosial, Dan Agama, 12(01), 59-70. https://doi.org/10.37680/qalamuna.v12i01.290

Turley, C., \& Graham, C. R. (2019). Interaction, student satisfaction, and teacher time investment in online high school courses. Journal of Online Learning Research, 5(2), 169-198.

Wen, K. Y. K., \& Hua, T. K. (2020). Esl teachers' intention in adopting online educational technologies during covid-19 pandemic. Journal of Education and E-Learning Research, 7(4), 387-394. https://doi.org/10.20448/journal.509.2020.74.387.394

Yanawut Chaiyo, R. N. (2017). The effect of Kahoot, Quizizz and Google Forms on the student's perception in the classrooms response system. IEEE. https://doi.org/10.1109/ICDAMT.2017.7904957

Yustinaningrum, B. (2018). The Implementation of E-Learning Web-based Model Centric Course (Edmodo) toward The Mathematics' Interest and Learning Outcomes. Al-Jabar : Jurnal Pendidikan Matematika, 9(1), 25. https://doi.org/10.24042/ajpm.v9i1.2175

Zain, F. M., Hanafi, E., Don, Y., Yaakob, M. F. M., \& Sailin, S. N. (2019). Investigating student's acceptance of an EDMODO content management system. International Journal of Instruction, 12(4), 1-16. https://doi.org/10.29333/iji.2019.1241a

Zarzycka-Piskorz, E. (2016). Kahoot it or not?: Can games be motivating in learning grammar? Teaching English with Technology, 16(3), 17-36.

Zhu, C. (2012). Student satisfaction, performance, and knowledge construction in online collaborative learning. Educational Technology and Society, 15(1), 127-136. 